\title{
Establishment and characterization of Asian oral cancer cell lines as in vitro models to study a disease prevalent in Asia
}

\author{
SHARIFAH HAMID ${ }^{1}$, KUE PENG LIM ${ }^{1}$, ROSNAH BINTI ZAIN ${ }^{2}$, SITI MAZLIPAH ISMAIL ${ }^{2}$, \\ SHIN HIN LAU ${ }^{3}$, WAN MAHADZIR WAN MUSTAFA ${ }^{4}$, M. THOMAS ABRAHAM ${ }^{5}$, \\ NOOR AKMAR NAM ${ }^{1}$, SOO-HWANG TEO ${ }^{1}$ and SOK CHING CHEONG ${ }^{1}$
}

\author{
${ }^{1}$ Cancer Research Initiatives Foundation (CARIF), 2nd Floor Outpatient Centre, Subang Jaya Medical Centre, 47500 Subang \\ Jaya, Selangor; ${ }^{2}$ Oral Cancer Research and Co-ordinating Centre, University of Malaya, Kuala Lumpur; ${ }^{3}$ Stomatology \\ Unit, Institute for Medical Research, Jalan Pahang, 50588 Kuala Lumpur; ${ }^{4}$ Department of Oral and Maxillofacial \\ Surgery, Kuala Lumpur Hospital, 50588 Kuala Lumpur; ${ }^{5}$ Department of Oral and Maxillofacial Surgery, \\ Tengku Ampuan Rahimah Hospital, Klang, Selangor, Malaysia
}

Received August 30, 2006; Accepted October 19, 2006

\begin{abstract}
We have established 3 cell lines ORL-48, -115 and -136 from surgically resected specimens obtained from untreated primary human oral squamous cell carcinomas of the oral cavity. The in vitro growth characteristics, epithelial origin, in vitro anchorage independency, human papillomavirus (HPV) infection, microsatellite instability status, karyotype and the status of various cell cycle regulators and gatekeepers of these cell lines were investigated. All 3 cell lines grew as monolayers with doubling times ranging between 26.4 and $40.8 \mathrm{~h}$ and were immortal. Karyotyping confirmed that these cell lines were of human origin with multiple random losses and gains of entire chromosomes and regions of chromosomes. Immunohistochemistry staining of cytokeratins confirmed the epithelial origin of these cell lines, and the low degree of anchorage independency expressed by these cell lines suggests non-transformed phenotypes. Genetic analysis identified mutations in the p53 gene in all cell lines and hypermethylation of $\mathrm{p} 16^{\mathrm{INK} 4 \mathrm{a}}$ in ORL-48 and -136. Analysis of MDM2 and EGFR expression indicated MDM2 overexpression in ORL-48 and EGFR overexpression in ORL-136 in comparison to the protein levels in normal oral keratinocytes. Analysis of the BAT-26 polyadenine repeat sequence and MLH-1 and MSH-2 repair enzymes demonstrated that all 3 cell lines were microsatellite stable. The role of HPV in driving carcinogenesis in these tumours was negated by the absence of HPV. Finally, analysis of the
\end{abstract}

Correspondence to: Dr Sok Ching Cheong, Cancer Research Initiatives Foundation (CARIF), 2nd Floor Outpatient Centre, Subang Jaya Medical Centre, 47500 Subang Jaya, Selangor, Malaysia

E-mail: sok_ching@carif.com.my

Key words: oral squamous cell carcinoma, cell line tissues from which these cell lines were derived indicated that the cell lines were genetically representative of the tumours, and, therefore, are useful tools in the understanding of the molecular changes associated with oral cancers.

\section{Introduction}

Oral cancer is the 8th and 13th most common cancer worldwide for males and females, respectively (1), and $80 \%$ of these cases occur in the Asian region. Amongst the multiethnic population of Malaysia, oral cancer is a disease most commonly seen in the Indian ethnic group. The age standardized rate (ASR) of oral cancer occurrence in Malaysian male Indians was comparable to that of Indian males from high-incidence regions in the Indian subcontinent, but the ASR for female Indians in Malaysia was markedly higher (2). Despite advances in cancer diagnosis and treatment, there has been little improvement in the 5-year survival rate of oral cancer patients in the last few decades.

While oral cancer is generally associated with smoking or betel quid chewing habits, the genetic alterations identified in smoking-related oral cancers differ from those observed in oral cancers associated with betel quid chewing (3). However, although its aetiological factors are well-established, the mechanism through which oral cancer develops is still largely unknown, partly due to the lack of in vitro and in vivo models of oral carcinogenesis. As a result, most studies focus on oral cancer tissues, which are pivotal in any research setting and represent real changes in the tumour $(4,5)$, but they are by definition limited. In addition, genetic manipulations to examine gene function as well as the up- and down-stream effects of such changes are restricted when working with tissue. Cell lines which are representative of particular cancers, on the other hand, make useful laboratory models to study genes and proteins implicated in the initiation and progression of cancers. For example, molecular targets regulated by epidermal growth factor (EGF) and TGFß were identified through experiments on oral cell lines established from either the primary tumour or a lymph node metastasis 
(6), and oral cancer cell lines have been used to study combinatory growth inhibitory effects of a COX-2 selective inhibitor and photodynamic therapy as a potential treatment for oral cancer (7). More specifically, the myriad of genes and proteins reported to be differentially expressed between normal and tumour tissues extracted from high-throughput gene expression arrays or tissue microarrays need such in vitro models to validate their specific role(s) in driving cancers. Therefore the establishment of such in vitro models to study tumours will aid in the understanding of molecular events associated with the development of these cancers. Moreover, novel therapeutic strategies can be tested in these cell lines for preliminary prediction of their efficacy. Here we describe the establishment and characterization of 3 oral cancer cell lines derived from 3 different individuals. Growth and genetic characteristics of these cell lines have been investigated, and these cell lines have been shown to be genetically representative of the tissues from which they were derived. Therefore, these cell lines will serve as useful molecular tools to unravel the regulatory pathways in oral cancer initiation and development towards a better understanding of oral cancer biology.

\section{Materials and methods}

Tumour specimen and tissue collection. Cell lines were derived from surgically resected tissue specimens from 3 different oral squamous cell carcinoma patients receiving treatment at the Dental Faculty and University Malaya Medical Centre, Kuala Lumpur Hospital and Tengku Ampuan Rahimah Hospital, respectively. These patients had received no treatment prior to surgery. Informed consent was obtained from all individuals, and this project was approved as part of a main study on 'Oral Cancer and Precancer in Malaysia' by the Medical Ethics Committee, Faculty of Dentistry, University Malaya and endorsed by the Ministry of Health, Malaysia (Medical Ethics Clearance no. DP OP0306/0018/L). Information on the patients and specimens from which the cell lines were derived are tabulated in Table I. Tissues were collected in sterile 30-ml universal bottles containing $10 \mathrm{ml}$ $\alpha$-MEM medium (Cambrex, USA) supplemented with $10 \%$ (v/v) fetal bovine serum (FBS), antibiotic solution (200 iu/ $\mathrm{ml}$ penicillin and $200 \mu \mathrm{g} / \mathrm{ml}$ streptomycin) and fungizone $(5 \mu \mathrm{g} / \mathrm{ml})$ immediately upon excision of the tumour.

Primary culture of the human oral squamous cell carcinoma cell lines and normal oral keratinocytes. The tissues were soaked in absolute ethanol for 20-30 sec and then washed twice with phosphate-buffered saline (PBS) under sterile conditions in the laboratory. Tissues were minced, washed in culture media twice and re-suspended in $\alpha$-MEM containing $20 \%$ (v/v) FBS, $200 \mathrm{iu} / \mathrm{ml}$ penicillin, $200 \mu \mathrm{g} / \mathrm{ml}$ streptomycin, $0.4 \mathrm{ng} / \mathrm{ml} \mathrm{EGF,} 2 \mu \mathrm{g} / \mathrm{ml}$ hydrocortisone and $2 \mathrm{mM}$ L-glutamine and seeded into 60-mm tissue culture dishes. All cultures were incubated in a humidified atmosphere of $5 \%$ $\mathrm{CO}_{2}$ at $37^{\circ} \mathrm{C}$. The culture medium was changed after $72 \mathrm{~h}$. From this point, cells were grown in $\alpha$-MEM with the above supplements along with $10 \%$ (v/v) FBS. Host fibroblast contamination was removed by trypsinisation $(0.2 \%)$, and cells were passaged routinely every week. Normal oral mucosa tissues were washed in ethanol and PBS as described above and incubated in $2.5 \mathrm{ml}$ of $1 \%$ trypsin type III (Sigma) containing $200 \mathrm{iu} / \mathrm{ml}$ penicillin and $200 \mu \mathrm{g} / \mathrm{ml}$ streptomycin at $4^{\circ} \mathrm{C}$ for $16 \mathrm{~h}$ followed by incubation at $37^{\circ} \mathrm{C}$ for $30 \mathrm{~min}$. Five milliliters of $\alpha-\mathrm{MEM} / \mathrm{FBS}$ was added and the mixture was pipetted vigorously to disaggregate the cells within the tissue. The cells were pelleted and washed in PBS twice and re-suspended in keratinocyte serum-free medium (KSFM, Invitrogen) containing $200 \mathrm{iu} / \mathrm{ml}$ penicillin, $200 \mu \mathrm{g} / \mathrm{ml}$ streptomycin, $0.4 \mathrm{ng} / \mathrm{ml} \mathrm{EGF,} 25 \mu \mathrm{g} / \mathrm{ml}$ bovine pituitary extract (BPE) and $30 \mu \mathrm{M}$ calcium chloride and seeded into $25-\mathrm{cm}^{2}$ culture flasks.

Growth curves. Growth curves were generated for all cells by taking triplicate cell counts with a haemacytometer each time the cells were subcultured. The cell counts were used to calculate the population doubling of the cells.

Immunostaining for cytokeratin. Keratin was examined in all the cultured cells. The cells were grown on glass coverslips, washed twice with PBS and fixed with acetone for $10 \mathrm{~min}$. After 2 PBS washes, the cells were incubated with anti-

Table I. Demographic details of donor patients from whom the cell lines were derived.

\begin{tabular}{|c|c|c|c|c|c|c|c|c|}
\hline $\begin{array}{l}\text { Patient } \\
\text { code }\end{array}$ & $\begin{array}{l}\text { Patient } \\
\text { age } \\
\text { (years) }\end{array}$ & Gender & Ethnicity & $\begin{array}{l}\text { Site of } \\
\text { tumour } \\
(\mathrm{ICD}-10)\end{array}$ & Diagnosis $^{\mathrm{a}}$ & $\begin{array}{l}\text { Pathological } \\
\text { staging }\end{array}$ & Oral habits & $\begin{array}{l}\text { Current } \\
\text { disease } \\
\text { status }\end{array}$ \\
\hline ORL-48 & 79 & Female & Sikh & $\begin{array}{l}\text { Mouth } \\
\text { Gum }\end{array}$ & $\begin{array}{c}\text { SCC } \\
\text { (well-differentiated) }\end{array}$ & $\mathrm{T}_{4} \mathrm{~N}_{2 \mathrm{a}} \mathrm{M}_{\mathrm{x}}$ & None & Deceased \\
\hline ORL-115 & 75 & Female & Indian & $\begin{array}{l}\text { Mouth } \\
\text { Cheek }\end{array}$ & $\begin{array}{c}\text { SCC } \\
\text { (well-differentiated) }\end{array}$ & $\mathrm{T}_{2} \mathrm{~N}_{\mathrm{x}} \mathrm{M}_{0}$ & $\begin{array}{c}\text { Chewed betel } \\
\text { quid }\end{array}$ & Deceased \\
\hline ORL-136 & 57 & Male & Indian & Tongue & $\begin{array}{c}\text { SCC } \\
\text { (well-differentiated) }\end{array}$ & $\mathrm{T}_{1} \mathrm{~N}_{0} \mathrm{M}_{0}$ & $\begin{array}{c}\text { Chewed betel } \\
\text { quid } \\
\text { Smoked }\end{array}$ & $\begin{array}{l}\text { Defaulted } \\
\text { treatment }\end{array}$ \\
\hline
\end{tabular}

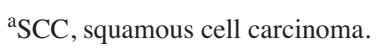


cytokeratin monoclonal antibody (1:250 in PBS; Dako Cytomation). To exclude the possibility that the established cell lines were fibroblasts, a separate coverslip with the respective cells was incubated with anti-fibroblast monoclonal antibody (1:250 in PBS; Dako Cytomation). The coverslips were processed using the Dako Cytomation Envision kit following the manufacturer's instructions, and all incubations were carried out at room temperature. The presence of target proteins was visualized using diaminobenzidine (DAB) as a chromogen, and the cells were counter-stained with Mayer's hematoxylin and mounted with DPX mountant. The cells were examined under a light microscope.

Assays of malignancy. The capacity of the established cell lines to grow in semi-solid media in vitro was monitored by soft agar assays as described elsewhere, with minor modifications (8). $\alpha$-MEM (2.5 ml) supplemented with $10 \%$ FBS, $0.4 \mathrm{ng} / \mathrm{ml} \mathrm{EGF,} 2 \mu \mathrm{g} / \mathrm{ml}$ hydrocortisone and $2 \mathrm{mM}$ L-glutamine containing 1\% low-gelling agarose (Sigma A 4018) was allowed to set in each 4-ml dish and was overlaid with $2 \mathrm{ml}$ of media containing $0.4 \%$ low-gelling agarose and $2.5 \times 10^{4}$ cells. Triplicate cultures were incubated for each cell line. Two milliliters of media was added on day 7 , and after 14 days the number of colonies ( $>30$ cells) was counted in 10 random microscopic fields (x20 objective), and the percentage of cells expressing anchorage independence (colony-forming efficiency; CFE) was calculated.

Immunoblotting. Keratinocytes were grown to semiconfluence in 100-mm culture dishes, following which, the cells were trypsinized, pelleted and lysed in cold RIPA buffer $(100 \mathrm{mM} \mathrm{NaCl}, 10 \mathrm{mM}$ Tris- $\mathrm{HCl} \mathrm{pH} 7.6,1 \mathrm{mM}$ EDTA, $0.2 \mathrm{mg}$ Aprotinin, $0.1 \mathrm{mM}$ PMSF, $5 \mathrm{mM}$ DTT and $1 \%$ Triton $\mathrm{X}-100$ ) for $20 \mathrm{~min}$ on ice. This was spun down at $13,000 \mathrm{rpm}$ for $10 \mathrm{~min}$ at $4^{\circ} \mathrm{C}$, and the supernatant containing total cell protein was stored at $-70^{\circ} \mathrm{C}$ for further analysis. Total protein concentration was determined using the Coomasie Protein Standard kit (Pierce). Crude protein extracts $(40 \mu \mathrm{g} /$ lane) resolved by SDS-PAGE were transferred onto nitrocellulose membrane using the Bio-Rad mini gel electrophoresis apparatus for $1 \mathrm{~h}$ in transfer buffer $(25 \mathrm{mM}$ Tris base, $192 \mathrm{mM}$ glycine and 20\% methanol, $\mathrm{pH}$ 8.3). Nitrocellulose membranes were treated with blocking solution (5\% skimmed milk/PBS) for $1 \mathrm{~h}$ at room temperature and probed with the following primary antibodies: anti-MLH-1 monoclonal antibody (1:250; BD Pharmingen), anti-human MSH-2 (1:250; BD Pharmingen), anti-p53 (1:1000; Santa Cruz Biotechnology), anti-MDM2 monoclonal antibody (1:100; Novocastra) or anti-epidermal growth factor receptor (EGFR) monoclonal antibody (1:200; Clone 31G7, Zymed) for $16 \mathrm{~h}$. Following incubation with the primary antibody, the blots were washed with PBS/0.1\% Tween-20 and probed with the secondary antibody conjugated to HRP for $1 \mathrm{~h}$ at room temperature, followed by washing with $\mathrm{PBS} / 0.1 \%$ Tween-20. To normalize for loading, the blots were probed with anti-actin monoclonal antibody (1:1,000; Chemicon) for $1 \mathrm{~h}$ at room temperature and processed as described above. The target proteins were detected by enhanced chemiluminescence method (Pierce) and visualized using the ChemiImager ${ }^{\text {TM }}$ Imaging Systems (Alpha Innotech).
Analysis of microsatellite instability (MSI). MSI status was determined by screening the polyadenine sequence BAT-26, by PCR amplification of the repeat sequence. PCR was performed with primers 5' TGACTACTTTTGACTTCAGCC 3' and 5' AACCATTCAACATTTTTAACCC 3' as described elsewhere (9). The amplified products were separated on $12 \%$ polyacrylamide gel and stained with ethidium bromide.

Methylation specific polymerase chain reaction (MSP) and homozygous deletion of $p 16^{I N K 4 a}$ and $p 14^{A R F}$. Genomic DNA was isolated from ORL-48, -115 and -136 cells using the QIAamp DNA mini kit (Qiagen, USA). Methylation of $\mathrm{p} 16^{\mathrm{INK} 4 \mathrm{a}}$ and $\mathrm{p} 14^{\mathrm{ARF}}$ was investigated using the CP Genome DNA modification kit (Intergene). Following DNA modification, PCR was performed using primers described elsewhere either targeting for wild-type DNA, methylated DNA or unmethylated DNA $(10,11)$. PCR was also performed on unmodified DNA samples. PCR was performed in a 50- $\mu 1$ reaction mixture containing $10 \mathrm{mM}$ Tris- $\mathrm{HCl} \mathrm{pH} 9.0,50 \mathrm{mM}$ $\mathrm{KCl}, 1.5 \mathrm{mM} \mathrm{MgCl}$ and $0.1 \%$ Triton X-100, $200 \mu \mathrm{M}$ dNTPs, 2.5 U TaqDNA polymerase (Promega, Madison, WI, USA) and $100 \mathrm{ng}$ of genomic DNA. PCR amplification was carried out in the GeneAmp PCR System 9700 (Applied Biosystems, USA). The PCR conditions were $95^{\circ} \mathrm{C}$ for $2 \mathrm{~min}$, followed by 30 cycles of $95^{\circ} \mathrm{C}$ denaturing for $30 \mathrm{sec}, 62-68^{\circ} \mathrm{C}$ annealing for $30 \mathrm{sec}$ (primer-dependent) and $72^{\circ} \mathrm{C}$ elongation for $30 \mathrm{sec}$. The final extension was conducted for $4 \mathrm{~min}$ at $72^{\circ} \mathrm{C}$. Methylated DNA included in the kit was used as a positive control in the DNA modification procedure and PCR. For homozygous deletion analyses of $\mathrm{p} 16^{\mathrm{INKa}}$, both exons 1 and 2 were amplified simultaneously with the $\beta$-actin gene. PCR conditions were as described above and primer sequences were as previously reported (11). Exon $1 ß$ of the $p 14^{A R F}$ gene was amplified under the same conditions, and $\beta$-globin was coamplified with the 5 ' region whilst $\beta$-actin was coamplified with the $3^{\prime}$ region of exon $1 B$ of the $p 14^{A R F}$ gene, and the amplicons were electrophoresed on a $4 \%$ agarose gel for deletion assessment. Primer sequences used were as previously published (12).

Mutational analysis of TP53 and epidermal growth factor receptor $(E G F R)$. Genomic DNA was isolated as described above. Exons 4-10 of the TP53 gene were amplified using PCR. The TP53 primers were designed in the intronic region using the Primer Express software (Applied Biosystems, USA) or as previously published (12). Primer sequences were: exon 4, sense 5' ACTTCCTGAAAACAACGTTCT 3' and antisense 5' CAGGCATTGAAGTCTCATGG 3'; exon 9, sense 5' GCAGTTATGCCTCAGATTCA 3' and antisense 5' GGCATTTTGAGTGTTAGACT 3'; and exon 10, sense 5' GGTACTGTGTATATACTTAC 3' and antisense 5' ATGAG AATGGAATCCTATGG 3'. PCR was performed in a 50- $\mu 1$ reaction mixture containing $10 \mathrm{mM}$ Tris- $\mathrm{HCl} \mathrm{pH} 9.0,50 \mathrm{mM}$ $\mathrm{KCl}, 1.5 \mathrm{mM} \mathrm{MgCl}_{2}$ and $0.1 \%$ Triton X-100, $200 \mu \mathrm{M}$ dNTPs, 2.5 U TaqDNA polymerase (Promega) and $100 \mathrm{ng}$ of genomic DNA. PCR amplification was carried out in the GeneAmp PCR System 9700. The PCR conditions were $95^{\circ} \mathrm{C}$ for $2 \mathrm{~min}$, followed by 30 cycles of $95^{\circ} \mathrm{C}$ denaturing for $30 \mathrm{sec}, 49-57^{\circ} \mathrm{C}$ annealing for $30 \mathrm{sec}$ (primer dependent) and $72^{\circ} \mathrm{C}$ elongation for $30 \mathrm{sec}$. The final extension was conducted 

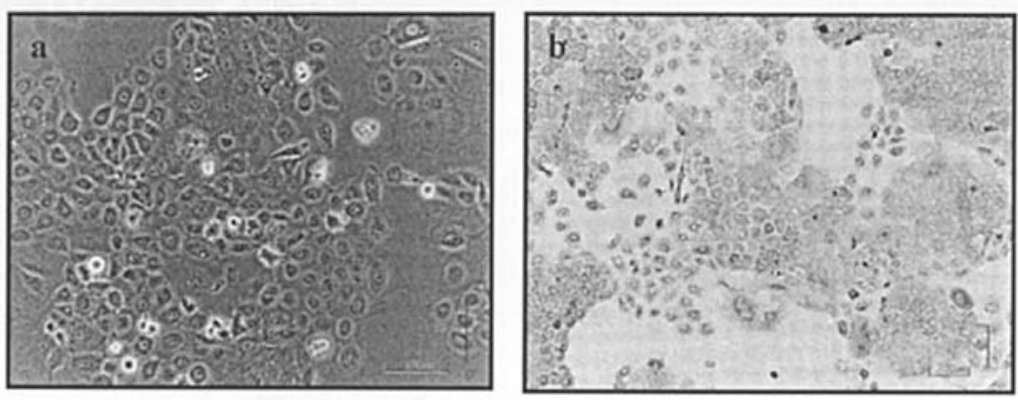

Figure 1. (a) Photomicrograph of ORL-48 cells in culture and (b) ORL-48 stained with anti-cytokeratin monoclonal antibody (1:250) confirming the keratinocyte origin of these cells. Original magnification, x100.

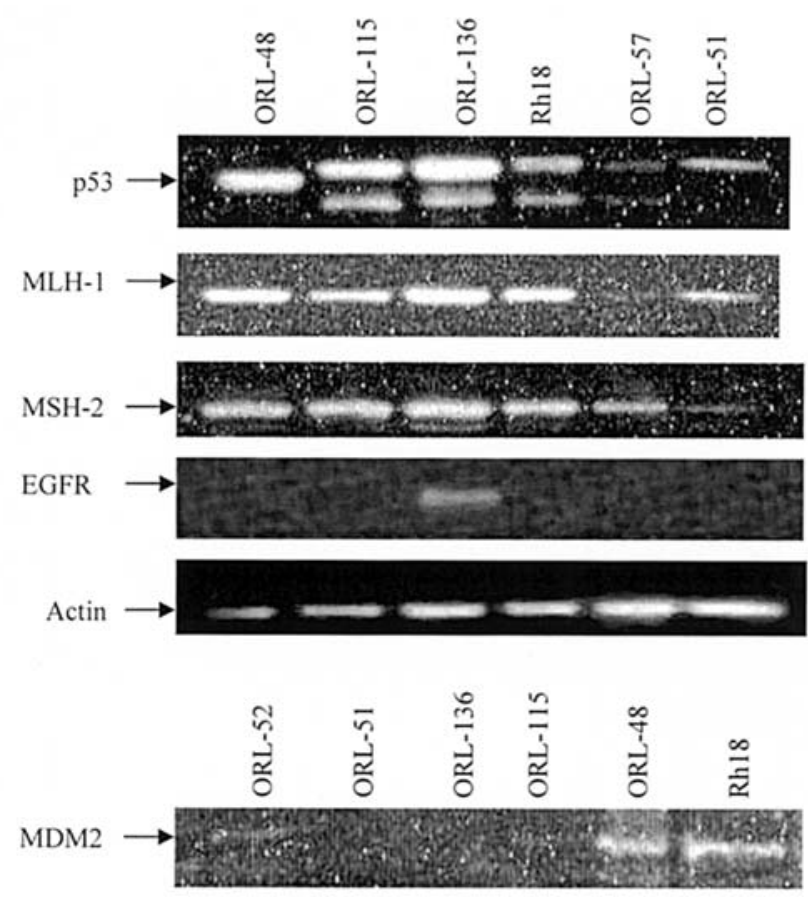

Figure 2. Western blots demonstrating the expression of TP53, MLH-1, MSH-2, EGFR and MDM2 in ORL-48, $-115,-136$ and normal oral keratinocyte cell lines (ORL-57, -52 and -51$)$. Rh18 cells were used as a positive control for MDM2 expression. The blot was probed with anti-actin monoclonal antibody to correct for possible differences in the loading of total protein in each well.

for $4 \mathrm{~min}$ at $72^{\circ} \mathrm{C}$. Exons $18-21$ which encode the tyrosine kinase domain of the EGFR gene were amplified as above with PCR conditions as follows: $95^{\circ} \mathrm{C}$ for $2 \mathrm{~min}$, followed by 30 cycles of $95^{\circ} \mathrm{C}$ denaturing for $30 \mathrm{sec}, 52-58^{\circ} \mathrm{C}$ annealing for $30 \mathrm{sec}$ (primer-dependent) and $72^{\circ} \mathrm{C}$ elongation for $30 \mathrm{sec}$. The final extension was conducted for $4 \mathrm{~min}$ at $72^{\circ} \mathrm{C}$. PCR primers used were as reported by Lynch and colleagues (13). TP53 and EGFR PCR products were purified using either the QIAamp PCR purification kit (Qiagen, Germany) or the QIAamp gel extraction kit (Qiagen). Purified products were sequenced using the DYEnamic ET Terminator cycle sequencing kit (Amersham Biosciences, UK). The primers used in the cycle sequencing reactions were similar to those used in PCR. Both DNA strands were sequenced, and the cycle sequencing products were electrophoresed on the MegaBACE ${ }^{\text {тм }} 500$ automated sequencer (Amersham
Biosciences). Sequences for the individual exons were checked for mutations by comparing them to known normal sequences from GenBank.

HPV analysis. The presence of HPV was determined by PCR using a combination of the general primers GP5+ and GP6+ which amplify the L1 region from all types of HPV genomes (14). PCR was performed in a $50-\mu 1$ reaction mixture containing $10 \mathrm{mM}$ Tris- $\mathrm{HCl} \mathrm{pH} 9.0,50 \mathrm{mM} \mathrm{KCl}, 1.5 \mathrm{mM}$ $\mathrm{MgCl}_{2}, 0.1 \%$ Triton X-100, $200 \mu \mathrm{M}$ dNTPs, $2.5 \mathrm{U}$ TaqDNA polymerase (Promega) and $100 \mathrm{ng}$ of genomic DNA. PCR amplification was carried out in the GeneAmp PCR System 9700. The PCR conditions were $94^{\circ} \mathrm{C}$ for $2 \mathrm{~min}$, followed by 30 cycles of $94^{\circ} \mathrm{C}$ denaturing for $30 \mathrm{sec}, 40^{\circ} \mathrm{C}$ annealing for $2 \mathrm{~min}$ and $72^{\circ} \mathrm{C}$ elongation for $1.5 \mathrm{~min}$. The final extension was conducted for $7 \mathrm{~min}$ at $72^{\circ} \mathrm{C}$. HPV DNA clones which were kind gifts from Professor de Villiers were included as positive controls for the PCR.

Karyotyping of cell lines. ORL-48, -115 and -136 cell lines were treated with uridine $(0.4 \mathrm{mM})$ and fluorodeoxyuridine $(5 \mu \mathrm{M})$ for $16 \mathrm{~h}$ at $37^{\circ} \mathrm{C}$, followed by colcemid $(10 \mu \mathrm{g} / \mathrm{ml})$ for $5 \mathrm{~h}$ at $37^{\circ} \mathrm{C}$. The adherent cells were removed with a cell scraper and treated with hypotonic $\mathrm{KCl}(0.075 \mathrm{M})$ for $30 \mathrm{~min}$ followed by fixation in fresh methanol:glacial acetic acid $(3: 1, \mathrm{v} / \mathrm{v})$ for $10 \mathrm{~min}$ at room temperature. Slides were stained by the trypsin-Giemsa technique and at least 20 metaphases were evaluated for each cell line.

\section{Results}

Behaviour of the in vitro cultures. All three oral squamous cell carcinoma (OSCC) cell lines grew as monolayers in culture with the population doubling ranging between 26.4 and $40.8 \mathrm{~h}$. ORL-48, -115 and -136 cells are immortal and currently at passage 28, 20 and 24 , respectively. The OSCC cells are typically polygonal and the morphological features of the cultured cells are shown in Fig. 1a. These OSCC cell lines stained positive for cytokeratin confirming its keratinocyte origin (Fig. 1b). Soft agar assays demonstrated that all 3 cell lines expressed a low degree of anchorage independency $(\mathrm{CFE}<6 \%)$.

Expression of MDM2 and EGFR. Overexpression of MDM2 has previously been shown to be a frequent event in oral cancers (12). Elevated levels of MDM2 protein in 


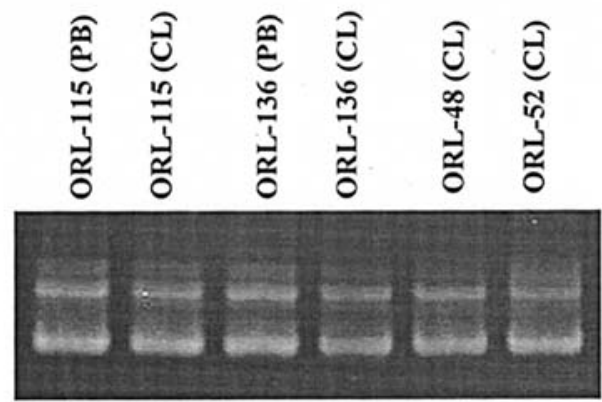

Figure 3. Analysis of the polyadenine repeat sequence BAT-26. The BAT26 region was amplified and separated in a denaturing polyacrylamide gel and stained with ethidium bromide. Amplicons from the cell lines (CL) were compared to the same region amplified from peripheral blood DNA (PB) of the same individual, and no alterations in the BAT-26 repeat sequence was found in any of the cell lines. DNA extracted from a normal oral keratinocyte cell line (ORL-52) was included.

comparison to normal oral keratinocytes were observed in ORL-48 (Fig. 2). The expression of EGFR is prominent in a variety of solid tumours including head and neck squamous cell carcinomas and is associated with a more aggressive disease, resistance to therapy, increased metastasis and poor clinical outcome. However, overexpression of EGFR in comparison to normal oral keratinocytes was only observed in ORL-136 and not in ORL-48 and -115 (Fig. 2).

Analysis of microsatellite instability. Since losses of MLH-1 and MSH-2 expression are known causes of inactivated mismatch repair function, the expression of these genes was analyzed. All 3 cell lines demonstrated the expression of MLH-1 and MSH-2 repair proteins (Fig. 2) suggesting that these enzymes are functional. In addition, the polyadenine sequence BAT-26 was analyzed using PCR to determine the

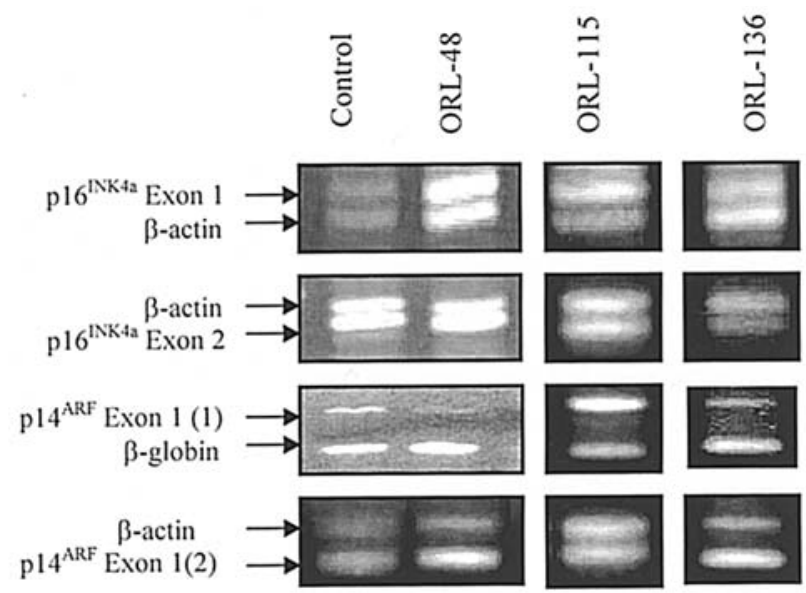

Figure 4. Agarose gel electrophoresis demonstrating that $\mathrm{p} 16^{\mathrm{INK} 4 \mathrm{a}}$ and $\mathrm{p} 14^{\mathrm{ARF}}$ genes were intact in ORL-48, -115 and -136 . p16 ${ }^{\mathrm{INK} 4 a}$ and $\mathrm{p} 14^{\mathrm{ARF}}$ genes were amplified simultaneously either with $\beta$-actin or $\beta$-globin. Control cells are known to have both $\mathrm{p} 16^{\mathrm{INK} 4 \mathrm{a}}$ and $\mathrm{p} 14^{\mathrm{ARF}}$ intact.

microsatellite instability status of our cells. None of the cell lines demonstrated microsatellite instability either at the BAT-26 polyadenine region (Fig. 3) or by the loss of MLH-1 and MSH-2 expression.

Analyses of cell cycle regulators and tumour suppressors. Methylation and gene deletion are mechanisms of inactivating the tumour suppressors $p 16^{I N K 4 a}$ and $p 14^{A R F}$. Gene deletion and the methylation status of both genes were investigated in ORL-48, -115 and -136 . Both genes were intact in all the cell lines (Fig. 4). However, p16 ${ }^{\mathrm{INK} 4 \mathrm{a}}$ was hypermethylated at the promoter region in ORL-48 and -136 suggesting that this gene is inactivated (data not shown). Mutations in the TP53 gene were detected in all cell lines. In

i) GАAАGGGБАБССТСАССАССАБСТССССС GAAGGGБAБССТСАССАСТАБСТССССС

a)

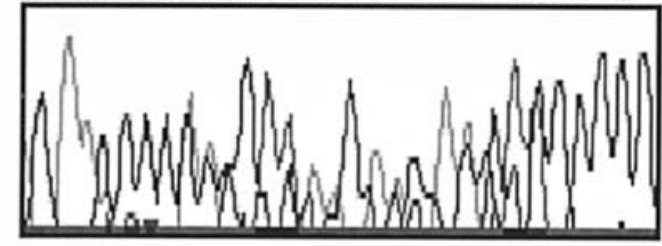

ii)

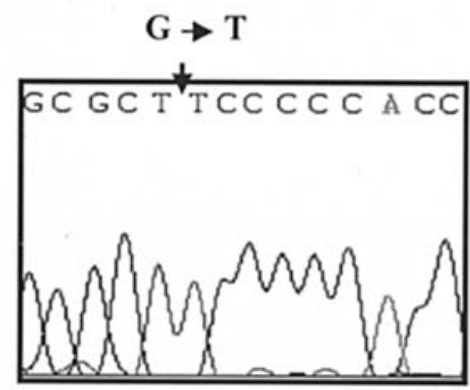

b)

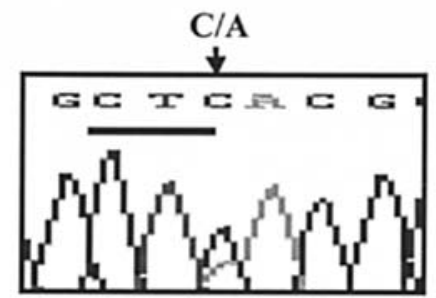

iii)

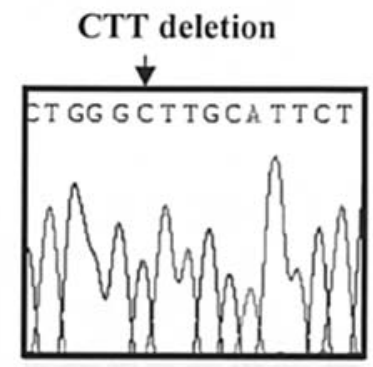

Figure 5. Sequence analysis of the TP53 gene. i) Electropherogram of the TP53 gene showing 2 different mutations in ORL-48. (a) c.876delA in exon 8 and (b) p.Glu336X in exon 10 (sequence in antisense direction). ii) Electropherogram of the TP53 gene showing the p.Cys176Phe alteration in ORL-136. iii) Electropherogram of the TP53 gene showing the c.336-338delCTT in-frame deletion in ORL-115. All mutations were confirmed by sequencing an independent PCR amplicon. 


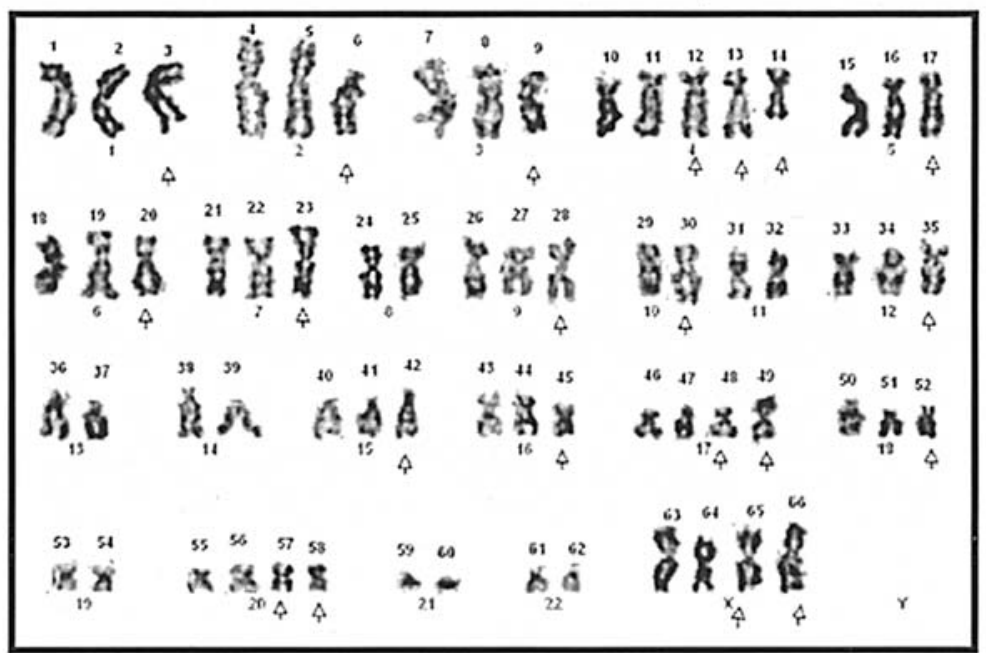

Figure 6. Karyotype analysis of ORL-48 cells showing a female karyotype with random gains and losses of regions and whole chromosomes.

Table II. Karyotype of ORL-48, -115 and -136 cell lines.

\begin{tabular}{ll}
\hline Cell line & \multicolumn{1}{c}{ Karyotype } \\
\hline ORL-48 & $64-73, \mathrm{XXX},+\mathrm{X}, \operatorname{der}(1) \mathrm{t}(1 ; 2)(\mathrm{p} 10 ; \mathrm{q} 10),+\operatorname{del}(1)(\mathrm{p} ? 22), 2,+\operatorname{del}(3)(\mathrm{p} 13),+\operatorname{del}(4)(\mathrm{q} 21)$, \\
& $+\operatorname{der}(4) \mathrm{hsr}(4)(\mathrm{q} 21 \mathrm{q} ? 31),-8, \mathrm{i}(9)(\mathrm{q} 10),-10,-10,-11,-13,-14,+\mathrm{i}(17)(\mathrm{q} 10),+20,-22,+\operatorname{mar}[15]$ \\
& $70-80, \mathrm{XX},-\mathrm{X},+\operatorname{der}(1) \mathrm{t}(1 ; 12)(\mathrm{p} 11 ; \mathrm{q} 11),+\operatorname{del}(1)(\mathrm{p} 13),+2,+3,+5,+8, \operatorname{der}(8) \mathrm{t}(8 ; ?)(\mathrm{q} 24 ; ?)$, \\
& $+9,+\mathrm{i}(10)(\mathrm{q} 10),+11,+11,+11,-12,-13, \operatorname{add}(13)(\mathrm{q} ? 34),+14,+16,-17,-18,-19,+20,+20,-21$, \\
& $-22,+\operatorname{mar} 1,+\operatorname{mar} 2[\mathrm{cp} 10]$ \\
& $74-82, \mathrm{XX}, \mathrm{YY}, \operatorname{add}(2)(\mathrm{p} ? 25), \operatorname{del}(6)(\mathrm{q} 21),-7,-8, \mathrm{i}(8)(\mathrm{q} 10), \operatorname{der}(10) \mathrm{t}(3 ; 10)(\mathrm{p} 10 ; \mathrm{q} 10)$, \\
& \\
ORL-136 & $\operatorname{del}(10)(\mathrm{p} 10),+11,-13,-14,-15,-17,-18,-19,+20,+20,-22,-22,-22,-22,+\operatorname{mar} 1,+\operatorname{mar} 2[\mathrm{cp} 18]$ \\
\hline
\end{tabular}

ORL-48, a deletion of an adenine was seen in nucleotide 876 in exon 8 , and a heterozygous mutation at nucleotide 1006 resulted in a stop codon in exon 10 (Fig. 5). In addition to the mutations observed in ORL-48, a polymorphism resulting in an arginine to proline amino acid change was detected in exon 4 which may explain the slight alteration in the molecular weight of the TP53 protein (Fig. 2). A 3-base inframe deletion in exon 4 (nt 336-338) was detected in ORL115 , while a $\mathrm{G}$ to $\mathrm{T}$ transition at nucleotide 527 in exon 5 was identified in ORL-136 resulting in a cysteine to phenylalanine amino acid change in codon 176 (Fig. 5). Mutations in exons 18-21 of the EGFR gene were undetected in these cell lines.

$H P V$ infection. HPV infection has been implicated in oral carcinogenesis. HPV infection in ORL-48, -115 and -136 was evaluated using PCR. None of the cell lines were infected with HPV.

Chromosome analyses. Chromosomal analysis of ORL-48 and -115 showed human female karyotype whilst ORL-136 showed a human male karyotype. All cell lines had an abnormal number of chromosomes ranging between 64 and 82 with random gains or losses of entire chromosomes or regions of the chromosomes (Fig. 6). The composite karyotype of each cell line is detailed in Table II.

\section{Discussion}

While the difficulties in developing oral cancer cell lines have been well-reported, the importance of these cell lines in the understanding of oral cancer biology is also wellrecognized. Several previously proposed reasons explaining the difficulties in establishing viable cultures include a limited tumour stem cell population and unfavorable culture conditions introduced by 3 T3 feeder cells $(15,16)$. Here we described the establishment and characterization of 3 OSCC cell lines established from individuals with and without habits associated with oral cancer. In our laboratory, the cultures appeared to be more viable when $3 \mathrm{~T} 3$ feeder cells were not used, therefore we resorted to establishing our cultures without the use of feeder layers. These cell lines grew as monolayers of polygonal cells and were shown to be immortal. Although the keratinocytes were more viable without the feeder cells, the lack of these cells encouraged the growth of host fibroblasts which had to be frequently removed with mild trypsinisation. We confirmed the human origin of these cells by karyotyping and demonstrated that the cells had near triploid and tetraploid number of chromosomes and that they gained and lost entire chromosomes or regions of chromosomes (Table II), a common characteristic of solid tumours (17). The epithelial origin of these cells was confirmed by cytokeratin expression, and the contamination 
of fibroblast cells in these cultures was negated by negative staining with an anti-fibroblast monoclonal antibody (data not shown). Anchorage independency has been reported to be indicative of a transformed phenotype by which cells can form tumours in vivo (18). None of these cell lines formed colonies in semi-solid agarose suggestive of non-transformed phenotypes, in contrast to previous reports of other OSCC cell lines readily exhibiting anchorage independent growth $(19,20)$. It is well-recognized that cancers develop as a result of the accumulation of sequential genetic alterations. As the TP53 and retinoblastoma (RB1) pathways are central in the control of cellular proliferation and senescence, it is not surprising that alterations within these pathways are frequently detected in cancers. We have examined our cell lines for the common genetic alterations reported in genes known to play major roles in the carcinogenesis process. Genetic characterization showed TP53 mutations in all 3 cell lines resulting either in a stop codon (in ORL-48) or amino acid changes (ORL-136). Two of these mutations (p.Glu336X and p.Cys176Phe) have previously been reported in head and neck tumours or cell lines (21-25). MDM2, a negative regulator of TP53 that has been reported to be overexpressed in cancers lacking TP53 mutations (26), has also been demonstrated to be over-expressed in oral cancers $(5,12,27)$. Surprisingly, amongst our cell lines, only ORL-48 demonstrated overexpression of the MDM2 protein in comparison to normal oral keratinocytes. Within the same pathway, p14 ${ }^{\mathrm{ARF}}$, a molecule known to regulate the function of MDM2, $(28,29)$ was observed to be intact in all the cell lines. Since the inactivation of $\mathrm{p} 16^{\mathrm{INK} 4 \mathrm{a}}$ has been reported to contribute to immortalization in epithelial cells (30), p16 $6^{I N K 4 a}$ which shares a similar locus to $p 14^{A R F}$ was unsurprisingly shown to be inactivated by hypermethylation of the promoter region in ORL-48 and ORL-136. However, the CDKN2a locus containing both the $p 16^{I N K 4 a}$ and $p 14^{A R F}$ genes remained intact in ORL-115 suggesting that the immortalization of these cells may occur through alternative mechanisms such as the overexpression of BMI-1 previously reported to extend cellular lifespan and confer immortality in fibroblasts $(31,32)$.

HPV infection has been implicated in a fraction of head and neck cancers (33), and frequently, HPV infection is detected in tumours with an intact TP53 pathway (34). However, the absence of HPV infection in all 3 cell lines suggests that HPV did not play a role in the pathogenesis of oral cancers in these particular individuals, indicating that the growth advantage of these tumours had already been provided by the inactivation of TP53. EGFR has been reported to be overexpressed in head and neck cancers and has been associated with poor clinical outcome (35-37). In view of this, EGFR has been targeted for the treatment of cancers, including head and neck (38-40). While EGFR overexpression is a common event in many cancers of epithelial origin, mutations within the tyrosine kinase domain have been reported to confer sensitivity to therapeutic interventions (13). We investigated the expression of EGFR in these cell lines and also screened for reported mutations within exons 18-21 of the EGFR gene. Overexpression of EGFR in comparison to normal oral keratinocytes was observed in ORL-136 but not in the other 2 cell lines.
Mutations within the tyrosine kinase domain of this gene were also unobserved in the cell lines. Microsatellite instability analyses indicated that all 3 cell lines were microsatellite stable with expression of both DNA mismatch repair enzymes (MLH-1 and MSH-2) intact. Similar genetic analyses were performed on the tissues from which these cell lines were derived with similar results, indicating that these cell lines closely resembled the tissues (data not shown). These cell lines which are genetically representative of the tissues from which they are derived will serve as useful tools in investigating the mechanisms of oral cancer development.

\section{Acknowledgements}

This study was funded by supporters of the Cancer Research Initiatives Foundation (CARIF). We thank Professor Stephen Prime for a critical review of the manuscript and Dr Maria Davies, Ms. Andrea Stone and Dr Karima Akhool Al-Salihi for the helpful discussions concerning laboratory techniques. We also thank Dr Pathmanathan Rajadurai and Ms. Sathiya Somiah for their assistance in karyotyping the cell lines. HPV clones which were kind gifts from Professor de Villiers (German Cancer Research Centre) and Rh18 cells from Dr Peter Houghton (St. Jude Children's Research Hospital) are gratefully acknowledged. CARIF is a non-profit research organization. We are committed to an understanding of cancer prevention, diagnosis and treatment through a fundamental research programme.

\section{References}

1. Parkin D, Bray F, Ferlay J and Pisani P: Global cancer statistics, 2002. CA Cancer J Clin 55: 74-108, 2005.

2. Lim GCC, Yahya H and Lim TO: The first report of the national cancer registry: cancer incidence in Malaysia. Kuala Lumpur: Ministry of Health, 2002.

3. Paterson IC, Eveson JW and Prime SS: Molecular changes in oral cancer may reflect aetiology and ethnic origin. Eur J Cancer B Oral Oncol 32B: 150-153, 1996.

4. Ekberg T, Nestor M, Engstrom M, et al: Expression of EGFR, HER2, HER3, and HER 4 in metastatic squamous cell carcinomas of the oral cavity and base of tongue. Int J Oncol 26: 1177-1185, 2005.

5. Huang JS, Ho TJ, Chiang CP, Kok SH, Kuo YS and Kuo MY: MDM2 expression in areca quid chewing-associated oral squamous cell carcinomas in Taiwan. J Oral Pathol Med 30: 53-58, 2001.

6. Miyazaki H, Patel V, Wang H, Ensley JF, Gutkind JS and Yeudall WA: Growth factor-sensitive molecular targets identified in primary and metastatic head and neck squamous cell carcinoma using microarray analysis. Oral Oncol 42: 240-256, 2006.

7. Akita Y, Kozaki K, Nakagawa A, et al: Cyclooxygenase-2 is a possible target of treatment approach in conjunction with photodynamic therapy for various disorders in skin and oral cavity. Br J Dermatol 151: 472-480, 2004.

8. Clark GJ, Cox AD, Graham SM and Der CJ: Biological assays for Ras transformation. Methods Enzymol 255: 395-412, 1995.

9. Hoang JM, Cottu PH, Thuille B, Salmon RJ, Thomas G and Hamelin R: BAT-26, an indicator of the replication error phenotype in colorectal cancers and cell lines. Cancer Res 57: 300-303, 1997.

10. Herman JG, Graff JR, Myohanen S, Nelkin BD and Baylin SB: Methylation-specific PCR: a novel PCR assay for methylation status of CpG islands. Proc Natl Acad Sci USA 93: 9821-9826, 1996.

11. Xing EP, Nie Y, Song Y, et al: Mechanisms of inactivation of p14ARF, p15INK4b, and p16INK4a genes in human esophageal squamous cell carcinoma. Clin Cancer Res 5: 2704-2713, 1999. 
12. Lim KP, Sharifah H, Lau SH, Teo SH and Cheong SC: Alterations of the p14ARF-p53-MDM2 pathway in oral squamous cell carcinoma: MDM2 overexpression is a common event. Oncol Rep 14: 963-968, 2005.

13. Lynch TJ, Bell DW, Sordella R, et al: Activating mutations in the epidermal growth factor receptor underlying responsiveness of non-small-cell lung cancer to gefitinib. N Engl J Med 350: 2129-2139, 2004.

14. de Roda Husman AM, Walboomers JM, van den Brule AJ, Meijer CJ and Snijders PJ: The use of general primers GP5 and GP6 elongated at their 3' ends with adjacent highly conserved sequences improves human papillomavirus detection by PCR. J Gen Virol 76: 1057-1062, 1995.

15. Moore GE, Merrick SB, Woods LK and Arabasz NM: A human squamous cell carcinoma cell line. Cancer Res 35: 2684-2688, 1975.

16. Rupniak HT, Rowlatt C, Lane EB, et al: Characteristics of four new human cell lines derived from squamous cell carcinomas of the head and neck. J Natl Cancer Inst 75: 621-635, 1985.

17. Kops GJ, Weaver BA and Cleveland DW: On the road to cancer: aneuploidy and the mitotic checkpoint. Nat Rev Cancer 5: 773-785, 2005

18. Shin SI, Freedman VH, Risser R and Pollack R: Tumorigenicity of virus-transformed cells in nude mice is correlated specifically with anchorage independent growth in vitro. Proc Natl Acad Sci USA 72: 4435-4439, 1975.

19. Kaur J and Ralhan R: Establishment and characterization of a cell line from smokeless tobacco associated oral squamous cell carcinoma. Oral Oncology 39: 806-820, 2003.

20. Lee G, Kim Y-B, Kim JH, et al: Characterization of novel cell lines established from three human oral squamous cell carcinomas. Int J Oncol 20: 1151-1159, 2002.

21. Brachman DG, Beckett M, Graves D, Haraf D, Vokes E and Weichselbaum RR: p53 mutation does not correlate with radiosensitivity in 24 head and neck cancer cell lines. Cancer Res 53: 3667-3669, 1993.

22. Bradford CR, Zhu S, Ogawa H, et al: P53 mutation correlates with cisplatin sensitivity in head and neck squamous cell carcinoma lines. Head Neck 25: 654-661, 2003.

23. Cabelguenne A, Blons H, de Waziers I, et al: p53 alterations predict tumor response to neoadjuvant chemotherapy in head and neck squamous cell carcinoma: a prospective series. J Clin Oncol 18: 1465-1473, 2000

24. Ganly I, Soutar DS, Brown R and Kaye SB: p53 alterations in recurrent squamous cell cancer of the head and neck refractory to radiotherapy. Br J Cancer 82: 392-398, 2000.

25. Temam S, Flahault A, Perie S, et al: p53 gene status as a predictor of tumor response to induction chemotherapy of patients with locoregionally advanced squamous cell carcinomas of the head and neck. J Clin Oncol 18: 385-394, 2000.

26. Cordon-Cardo C, Latres E, Drobnjak M, et al: Molecular abnormalities of mdm2 and p53 genes in adult soft tissue sarcomas. Cancer Res 54: 794-799, 1994.
27. Yanamoto S, Kawasaki G, Yoshitomi I and Mizuno A: p53, $\mathrm{mdm} 2$, and $\mathrm{p} 21$ expression in oral squamous cell carcinomas: relationship with clinicopathologic factors. Oral Surg Oral Med Oral Pathol Oral Radiol Endod 94: 593-600, 2002.

28. Honda R and Yasuda H: Association of p19(ARF) with Mdm2 inhibits ubiquitin ligase activity of $\mathrm{Mdm} 2$ for tumor suppressor p53. ЕMBO J 18: 22-27, 1999.

29. Tao W and Levine AJ: p14ARF stabilizes p53 by blocking nucleo-cytoplasmic shuttling of MDM2. Proc Natl Acad Sci USA 96: 6937-6941, 1999.

30. Kiyono T, Foster SA, Koop JI, McDougall JK, Galloway DA and Klingelhutz AJ: Both Rb/p16INK4a inactivation and telomerase activity are required to immortalize human epithelial cells. Nature 396: 84-88, 1998.

31. Itahana K, Zou Y, Itahana Y, et al: Control of the replicative life span of human fibroblasts by 16 and the polycomb protein Bmi-1. Mol Cell Biol 23: 389-401, 2003.

32. Jacobs JJ, Kieboom K, Marino S, DePinho RA and van Lohuizen M: The oncogene and Polycomb-group gene bmi-1 regulates cell proliferation and senescence through the ink4a locus. Nature 397: 164-168, 1999.

33. Ha PK and Califano JA: The role of human papillomavirus in oral carcinogenesis. Crit Rev Oral Biol Med 15: 188-196, 2004.

34. Gillison ML, Koch WM, Capone RB, et al: Evidence for a causal association between human papillomavirus and a subset of head and neck cancers. J Natl Cancer Inst 92: 709-720, 2000.

35. Ang KK, Berkey BA, Tu X, et al: Impact of epidermal growth factor receptor expression on survival and pattern of relapse in patients with advanced head and neck carcinoma. Cancer Res 62: 7350-7356, 2002.

36. Nicholson RI, Gee JM and Harper ME: EGFR and cancer prognosis. Eur J Cancer 37 (suppl 4): 9-15, 2001.

37. Rubin Grandis J, Melhem MF, Barnes EL and Tweardy DJ: Quantitative immunohistochemical analysis of transforming growth factor-alpha and epidermal growth factor receptor in patients with squamous cell carcinoma of the head and neck. Cancer 78: 1284-1292, 1996.

38. Baselga J, Rischin D, Ranson M, et al: Phase I safety, pharmacokinetic, and pharmacodynamic trial of ZD1839, a selective oral epidermal growth factor receptor tyrosine kinase inhibitor, in patients with five selected solid tumor types. J Clin Oncol 20: 4292-4302, 2002.

39. Herbst RS, Maddox AM, Rothenberg ML, et al: Selective oral epidermal growth factor receptor tyrosine kinase inhibitor ZD1839 is generally well-tolerated and has activity in nonsmall-cell lung cancer and other solid tumors: results of a phase I trial. J Clin Oncol 20: 3815-3825, 2002.

40. Kirby AM, A'Hern RP, D'Ambrosio C, et al: Gefitinib (ZD1839, Iressa) as palliative treatment in recurrent or metastatic head and neck cancer. Br J Cancer 94: 631-636, 2006. 